\title{
Solar CPC Pilot Plant Photocatalytic Degradation of Indigo Carmine Dye in Waters and Wastewaters Using Supported-TiO ${ }_{2}$ : Influence of Photodegradation Parameters
}

\author{
Enrico Mendes Saggioro, ${ }^{1,2,3}$ Anabela Sousa Oliveira, ${ }^{4,5}$ Thelma Pavesi, ${ }^{1}$ \\ Margarita Jiménez Tototzintle, ${ }^{6}$ Manuel Ignacio Maldonado, ${ }^{6}$ \\ Fábio Verissimo Correia, ${ }^{7}$ and Josino Costa Moreira ${ }^{1}$ \\ ${ }^{1}$ Centro de Estudos da Saúde do Trabalhador e Ecologia Humana (CESTEH), Escola Nacional de Saúde Pública, \\ Fundação Oswaldo Cruz, Avenida Leopoldo Bulhões 1480, 21041-210 Rio de Janeiro, RJ, Brazil \\ ${ }^{2}$ Programa de Engenharia Química (COOPE), Universidade Federal do Rio de Janeiro, P.O. Box 68502, \\ 21941-972 Rio de Janeiro, RJ, Brazil \\ ${ }^{3}$ Departamento de Patologia, Universidade Federal Fluminense (UFF), Avenida Marquês de Paraná 303, 24033-900 Niterói, RJ, Brazil \\ ${ }^{4}$ Centro Interdisciplinar de Investigação e Inovação and Escola Superior de Tecnologia e Gestão (C3i), \\ Instituto Politécnico de Portalegre, Lugar da Abadessa, Apartado 148, 7301-901 Portalegre, Portugal \\ ${ }^{5}$ Centro de Química-Física Molecular (CQFM-IN), Intituto de Nanociências e Nanotecnologias and Instituto Superior Técnico, \\ Universidade de Lisboa, Avenida Rovisco Pais, 1049-001 Lisboa, Portugal \\ ${ }^{6}$ Centro de Investigaciones Energéticas (CIEMAT), Medioambientales y Tecnológicas, Plataforma Solar de Almería, \\ Carretera Sénes km 4, 04200 Tabernas, Spain \\ ${ }^{7}$ Universidade Federal do Estado do Rio de Janeiro UNIRIO, Avenida Pasteur 296, 22290-240 Rio de Janeiro, RJ, Brazil
}

Correspondence should be addressed to Enrico Mendes Saggioro; saggi_br@hotmail.com

Received 30 October 2014; Revised 13 January 2015; Accepted 14 January 2015

Academic Editor: Jincai Zhao

Copyright (C) 2015 Enrico Mendes Saggioro et al. This is an open access article distributed under the Creative Commons Attribution License, which permits unrestricted use, distribution, and reproduction in any medium, provided the original work is properly cited.

\begin{abstract}
The photocatalytic degradation of indigo carmine (IC) dye in the presence of titanium dioxide under different conditions was reported. Several factors which interfere with the photodegradation efficiency as catalyst concentration, $\mathrm{pH}$, initial concentration of dye, presence of inorganic anions, temperature, and the addition of hydrogen peroxide were studied under artificial irradiation with a $125 \mathrm{~W}$ mercury vapor lamp. Additionally, the catalyst supported on glass spheres was used for the photocatalytic degradation of the dye present in several types of waters in a CPC solar pilot plant. The photocatalytic products, carboxylic acids, and $\mathrm{SO}_{4}{ }^{2-}$ and $\mathrm{NH}_{4}{ }^{+}$were followed during IC mineralization. Formate, acetate, and oxalate were detected in real MWWTP secondary effluent. The mineralization efficiency was of 42 and $21 \%$ using in suspension and supported $\mathrm{TiO}_{2}$, respectively. In order to evaluate biological effects, Eisenia andrei earthworms were used as a model organism. No significant difference $(P>0.05)$ of weight was observed in the earthworm submitted to different concentrations of IC and its photoproducts. The photocatalytic degradation of $\mathrm{IC}_{\mathrm{C}} \mathrm{TiO}_{2}$ supported on glass spheres suffered strong influence of the water matrix; nevertheless the method has the enormous advantage that it eliminates the need for the final catalyst removal step, reducing therefore the cost of treatment.
\end{abstract}

\section{Introduction}

Organic dyes are one of the largest groups of pollutants in wastewaters. In general, they are released into the environment by textile and some other industries [1]. Dyes are widely used in textile industries, and significant quantities are lost during the dyeing steps. Wastewaters containing $5-15 \%$ of the untreated dye can be released into the environment and are considered to pose severe problems to the ecosystem [2]. In general, environmental pollution by organic dyes sets a serious ecological problem since most of these compounds are 
often toxic to microorganisms and a have long degradation times in the environment [3].

Around 100,000 dyes are currently in use by textile industry and $7 \times 10^{5}$ ton of dyestuff is produced annually worldwide. Among these, the indigoids are the largest class of commercial dyes, used mostly for cotton cloth dying (blue jeans) $[4,5]$. The principal component of Indigo blue dye is indigotin, which is extracted from the leaves of Indigofera tinctoria [6]. Indigo carmine (3,3-dioxo-2,2-bis-indolyden5,5-disulfonic acid disodium salt) is also one of the oldest dyes and still one of the most used in the textile industry [7]. The primary color-producing structure of indigoid dyes is a crossconjugated system or $\mathrm{H}$-chromophore, consisting of a single $\mathrm{C}=\mathrm{C}-$ double bond substituted by two $\mathrm{NH}$ donor groups and two $\mathrm{CO}$ acceptor groups [8].

Indigo carmine (IC) is considered as a highly toxic indigoid dye. Contact with skin and eyes can cause permanent injury to cornea and conjunctiva and if consumed by oral via can cause disturbs in reproductive, developmental, and neuronal systems including death [9]. In addition, several toxic dyes are recalcitrant to biodegradation, causing decay in the efficiency of biological wastewater treatment plants also decreasing the efficiency of traditional physical-chemical wastewater treatment methods $[2,10]$.

To avoid these problems, advanced oxidative processes (AOPs) has been proposed. AOPs can generate free radicals such as hydroxyl radicals $\left({ }^{\circ} \mathrm{OH}\right)$ able to oxidize organic pollutants through several nonspecifics reactions [11, 12]. Among AOPs, heterogeneous photocatalysis has been very attractive for an efficient and promising economy [13-15]. Titanium dioxide is a well-known photocatalyst mostly used in photoreactions for wastewater treatment as suspensions [16]. The use of $\mathrm{TiO}_{2}$ has some advantages such as ease of handling, low cost, high photochemical reactivity, and nonspecific oxidative attack ability. In this way, it can promote the degradation of different target organic compounds with little change of operational parameters [3, 17-23]. Titanium dioxide mediated photooxidation is indeed used for environmental remediation, where toxic materials at low concentration are converted by different mechanism of reaction, to harmless oxidation products such $\mathrm{CO}_{2}$ and $\mathrm{H}_{2} \mathrm{O}$ [24]. Additionally, it can be used as an antibacterial agent because of its strong oxidation activity and hydrophilicity [25].

However, in the large-scale applications, the use of $\mathrm{TiO}_{2}$ suspensions requires the separation and recycling of $\mathrm{TiO}_{2}$ particles mainly of nanometric dimension from treated wastewater prior to discharge into the water bodies. This fact can be a great drawback for the application once it is a timeconsuming and expensive process. Alternatively, the catalyst may be immobilized on a suitable solid inert material, which eliminates the need of the catalyst removal step $[1,26]$ and permits its reuse for several times.

The aim of the present work is to investigate the photocatalytic oxidation of indigo carmine (IC) on different water matrices using $\mathrm{TiO}_{2}$ in suspensions and also supported on glass spheres under sunlight.

The latter was focused on a photoreaction system composed by compound parabolic collectors (CPC) installed at the "Plataforma Solar de Almería" (PSA, Spain). The system

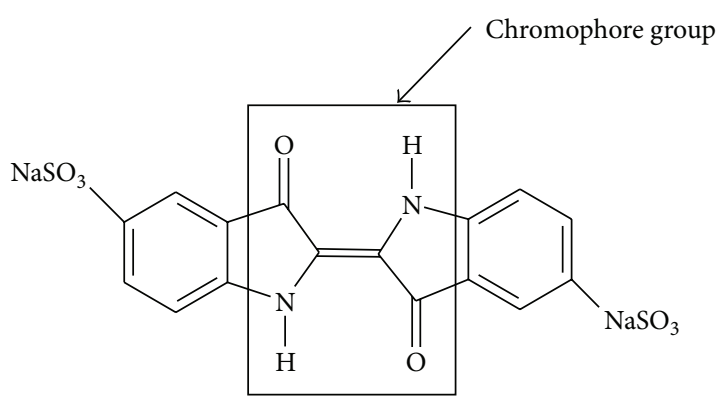

FIgURE 1: Chemical structure of IC.

already demonstrated having capacities to remove several other organic pollutants in large quantity from different water matrixes [27]. The dependence of various parameters on dye photooxidation was studied in the presence of $\mathrm{TiO}_{2}$ suspensions under artificial irradiation. These parameters included $\mathrm{TiO}_{2}$ amount, initial dye concentration, temperature, $\mathrm{H}_{2} \mathrm{O}_{2}$ addition, initial $\mathrm{pH}$, and some inorganic ions usually present in real wastewater produced by textile industry. The repeatability of photocatalytic activity of the photocatalyst was also tested.

Furthermore, acute ecotoxicological tests with Eisenia andrei earthworms were performed. The earthworms are affected by a variety of organic and inorganic compounds, which may cause bioaccumulation, and their preliminary results serve as a rapid indicator on the toxicity of the compounds. Moreover, it can be used as a complementary test for risk assessment of polluted areas [28]. Eisenia andrei has been chosen as test specie because it reproduces easily in the laboratory, and it was approved by the European Union and OECD for use in toxicity tests and has been employed by the US Environmental Protection Agency (EPA) as a broad test for contaminant residues in several polluted sites [29].

\section{Experimental}

2.1. Reagents and Materials. Indigo carmine (IC) dye (Figure 1), 85\% $\left(\mathrm{C}_{16} \mathrm{H}_{8} \mathrm{~N}_{2} \mathrm{~S}_{2} \mathrm{O}_{8} \mathrm{Na}_{2}\right.$, M.W. $\left.=466.36 \mathrm{gmol}^{-1}\right)$, was obtained from Sigma Aldrich (USA) and used without further purification. Titanium dioxide, EVONIK-P25, containing $75 \%$ anatase and $25 \%$ rutile, with a specific BET surface area of $50 \mathrm{~m}^{2} \mathrm{~g}^{-1}$ and primary particle size of $20 \mathrm{~nm}$, was used as photocatalyst in all experiments. The other chemicals such as $\mathrm{NaOH}, \mathrm{HCl}, \mathrm{H}_{2} \mathrm{O}_{2}, \mathrm{NaHCO}_{3}, \mathrm{NaCl}$, $\mathrm{Na}_{2} \mathrm{SO}_{4}$, and $\mathrm{KH}_{2} \mathrm{PO}_{4}$ were obtained from Merck.

2.2. Synthesis of Supported $\mathrm{TiO}_{2}$. The supported-TiO $\mathrm{TiO}_{2}$ photocatalyst was prepared by sol-gel technique [30]. Enough amount of distilled water was acidified with $13 \mathrm{~mL}$ of nitric acid and titanium isopropoxide, $\left(\mathrm{Ti}(\mathrm{iOPr})_{4}\right)$, (TIOP) was added to the solution and the suspensions were stirred for $24 \mathrm{~h}$, until complete peptization. A solution of $20 \mathrm{mgL}^{-1}$ of polyethylene glycol in isopropanol was prepared separately and added to the TIOP sol under constant magnetic stirring. The acid sol was dialyzed until a final pH of 2.4-2.5. Finally, 
TABle 1: Physical and chemical characteristics of the different types of water.

\begin{tabular}{llllllllllllll}
\hline Type of water & $\begin{array}{l}\text { Inorg. carbon } \\
\left(\mathrm{mgL}^{-1}\right)\end{array}$ & $\begin{array}{l}\mathrm{TOC} \\
\left(\mathrm{mgL}^{-1}\right)\end{array}$ & $\begin{array}{l}\mathrm{COD} \\
\left(\mathrm{mgL}^{-1}\right)\end{array}$ & $\mathrm{pH}$ & $\begin{array}{l}\text { Conduc. } \\
\left(\mu \mathrm{cm}^{-1}\right)\end{array}$ & $\mathrm{Na}^{+}$ & $\mathrm{Ca}^{+2}$ & $\mathrm{Mg}^{+2}$ & $\mathrm{~K}^{+}$ & $\mathrm{NH}_{4}^{+}$ & $\mathrm{PO}_{4}^{-3}$ & $\mathrm{Cl}^{-}$ & $\mathrm{SO}_{4}^{-2}$ \\
\hline $\begin{array}{l}\text { Fresh water } \\
\text { moderately hard }\end{array}$ & 13.89 & 3.40 & 11.6 & 7.4 & 206 & 0.76 & 0.36 & 0.44 & 0.1 & - & - & 0.09 & 0.04 \\
$\begin{array}{l}\text { Synthetic MWWTP } \\
\text { secondary effluent }\end{array}$ & 9.98 & 17.76 & 57.59 & 8.0 & 261 & 1.27 & 0.36 & 0.45 & 0.17 & 0.35 & 0.01 & 0.04 & 0.93 \\
$\begin{array}{l}\text { Real MWWTP } \\
\text { secondary effluent }\end{array}$ & 69.92 & 26.9 & 81.2 & 8.3 & 1504 & 8.2 & 1.5 & 1.3 & 0.63 & 2.96 & 0.05 & 9.94 & 1.02 \\
\hline
\end{tabular}

$10 \mathrm{gL}^{-1}$ of EVONIK P-25 $\mathrm{TiO}_{2}$ was incorporated under continuous stirring. The glass spheres were coated with $\mathrm{TiO}_{2}$ sol by dip coating. Then the glass spheres were dried at $110^{\circ} \mathrm{C}$ for $90 \mathrm{~min}$ and calcinated at $400^{\circ} \mathrm{C}$ for $5 \mathrm{~h} \mathrm{[31].} \mathrm{Approximately}$ $0.6 \mathrm{mg}$ of $\mathrm{TiO}_{2}$ on the surface of each glass bead [32].

\subsection{Photocatalytic Experiments with Artificial Irradiation. A} volume of $100 \mathrm{~mL}$ of indigo carmine solution $\left(30 \mathrm{mgL}^{-1}\right)$ was submitted to photodegradation using batch static stirred reactor with a high-pressure $125 \mathrm{~W}$ mercury vapor lamp to investigate the influence of various parameters on the photocatalytic degradation of IC by $\mathrm{TiO}_{2}$ suspension. Before irradiation, samples were kept in the dark for $30 \mathrm{~min}$, also under stirring. During irradiation step, samples were continuously stirred. Control samples were submitted to identical treatment. Samples were taken at different times and analyzed. The efficient photon flux was determinate measuring the radiant flux (in $\mathrm{mW} / \mathrm{cm}^{2}$ ) at the surface of the sample being treated. In each case stated above, the radiant flux was measured with a radiometer (Cole-Parmer Instrument Co.; model 9811-50) [33]. All experiments were performed in duplicate as described elsewhere.

\subsection{Photocatalytic Experiments in a CPC Solar Pilot Plant.} Solar $\mathrm{TiO}_{2}$ photocatalytic experiments were carried out in a pilot plant reactor with CPC optics installed at the Plataforma Solar de Almería (PSA, latitude $37^{\circ} \mathrm{N}$, longitude $2.4^{\circ} \mathrm{W}$ ). A schematic of the plant can be seen in a previous publication [34]. The reactor, which has sixteen DURAN glass tubes $(28.45 \mathrm{~mm}$ inner diameter) and was mounted on a fixed platform tilted $37^{\circ}$ (local latitude), was modified to work with only two of the glass tubes $\left(8 \mathrm{~L}\right.$ total volume and $0.250 \mathrm{~m}^{2}$ total irradiated surface). These two glass tubes were uniformly packed with the glass spheres ( 4600 spheres per tube, $\approx 0.6 \mathrm{mg}$ of $\mathrm{TiO}_{2}$ on the surface of each glass spheres). The pump flow was $2.5 \mathrm{~L} \mathrm{~min}^{-1}$ and the tank (containing the effluent to be treated) continuously stirred. A global UV radiometer (KIPP\&ZONEN, model CUV 3, the Netherlands) also tilted $37^{\circ}$ was used for measuring global solar UV radiation intensity $\left(\mathrm{UV}_{G}\right)$ in terms of incident $\mathrm{Wuv} / \mathrm{m}^{2}$.

The IC $\left(30 \mathrm{mgL}^{-1}\right)$ for each experiment was added in different types of water: distilled water, synthetic moderately hard freshwater [35], synthetic secondary municipal wastewater treatment plant (MWWTP) effluent [36], and secondary effluent from the MWWTP "El Bobar" (Almería, Spain). Table 1 shows some physical and chemical characteristics of the different types of water used in this work. Each experiment was homogenized for $30 \mathrm{~min}$ before sun irradiation. The solar pilot plant CPC was uncovered and the photocatalytic reaction started. The samples were taken at different times and analyzed. All experiments were performed in duplicate.

2.5. Evaluation of IC Degradation and Solar UV Radiation. In those cases where IC degradation was observed, IC concentration followed first-order kinetics according to

$$
\ln \left(\frac{[\mathrm{IC}]}{[\mathrm{IC}]_{0}}\right)=-k t
$$

where $k\left(\right.$ time $\left.^{-1}\right)$ is the pseudo-first-order rate constant. However, to compare the efficiency of the batch static stirred reactor with the solar CPC pilot plant, it is necessary to take into consideration that the reaction time needed to degrade IC also depends on the intensity of the incident UV radiation. So, IC degradation is expressed as a function of the accumulated UV energy in the reactor, $Q_{U V, n}$ :

$$
\ln \left(\frac{[\mathrm{IC}]}{[\mathrm{IC}]_{0}}\right)=-k^{\prime} \mathrm{Q}_{\mathrm{UV}, n}
$$

where $k^{\prime}$ is the pseudo-first-order rate constant $\left(\mathrm{LkJ}^{-1}\right)$ and $Q_{\mathrm{UV}, n}\left(\mathrm{~kJ} \mathrm{~L}^{-1}\right)$ is the amount of accumulated UV energy received on any surface in the same position with regard to the sun, per unit of volume of water inside the reactor in the interval $\Delta t . Q_{\mathrm{UV}, n}$ can be found by applying [37]

$$
\mathrm{Q}_{\mathrm{UV}, n}=\mathrm{QUV}, n-1+\Delta t \mathrm{UV}_{\mathrm{G}, n} \frac{\mathrm{A}_{i}}{V_{T}} ; \quad \Delta t=t_{n}-t_{n-1},
$$

where $t_{n}$ is the time corresponding to $n$ water sample, $V_{T}$ is the total reactor volume $(8 \mathrm{~L}), \mathrm{A}_{i}$ is the illuminated surface area $\left(0.25 \mathrm{~m}^{2}\right)$, and $\mathrm{UV}_{\mathrm{G} ; n}$ is the average solar ultraviolet radiation measured during the period $\Delta_{t n}$. This equation allows the combination of the data from experiments of several different days and their comparison with other photocatalytic experiments [38].

2.6. Analytical Determinations. The Indigo Carmine (IC) degradation was determined by UV-Visible spectrophotometry (Shimadzu UV-1601PC) acquired from 200-900 nm and HPLC-DAD (Agilent Technologies, series 1100) system equipped with a C-18 column (LUNA $5 \mathrm{~mm}, 3 \mathrm{~mm} \times 150 \mathrm{~mm}$, from Phenomenex) and using an ammonium acetate $10 \mathrm{mM}$ : 
methanol $(80: 20)$ mixture as mobile phase (flow rate: $\left.0.8 \mathrm{~mL} \mathrm{~min}^{-1}\right)$. Absorbance detection was made at $610 \mathrm{~nm}$. In order to determine the extent mineralization, total organic carbon (TOC) measured was performed on filtered samples using Shimadzu-5050A TOC analyzer. Anion concentrations were determined with a Metrohm 872 Extension Module-1 and -2 ion chromatograph (IC) system configured for gradient analysis. Cation concentrations were determined with a Metrohm 850 Professional IC configured for isocratic analysis. The hydrogen peroxide was determined by potassium permanganate method.

2.7. Ecotoxicological Tests. Photocatalytic degradation may generate toxic photoproducts and so they must be assessed in order to determine if the effluent treatment strategy is leading or not to the desired toxicity reduction result. Acting like that could prevent the contamination of receptor water bodies with toxic substances generated by decontamination treatment itself. In this work, the ecotoxicity of the indigo carmine and its photoproducts at different times were tested with Eisenia andrei earthworms.

Organisms Eisenia andrei used in the tests were created in the Ecotoxicology Sector, Laboratory of Toxicology in the Center of Occupational Health and Human Ecology Studies (CESTEH), Oswaldo Cruz Foundation (Fiocruz). Prior to the experiments, the earthworms were acclimated at least $24 \mathrm{~h}$ in the environment to be tested. To the test, adult worms were selected (under 2 months of age and well-developed clitellum) with individual weight around 300-600 mg [39]. The masses of earthworms survivors had their means were compared by ANOVA (analysis of variance) with Bonferroni correction (alpha bilateral 0.05), using BioEstat 2.0.

2.7.1. Acute Toxicity Test-Contact Test. Studies for acute toxicity $[40,41]$ were made with 15 replicates each concentration of IC by contacting each earthworm with filter paper $\left(60 \mathrm{~cm}^{2}\right)$ soaked with different concentrations $(0.17,1.67,16.67$, and 166 . $67 \mu \mathrm{g} \cdot \mathrm{cm}^{-2}$ ) of indigo solutions. As a control, 15 replicates on filter paper moistened with only $1 \mathrm{~mL}$ of pure water were also prepared.

After preparation of vessels, an earthworm was added to each of them, and the containers were sealed with perforated paraffin film, to enable oxygenation. After $24 \mathrm{~h}$ of incubation, the containers were opened, survivor and dead earthworms were counted, and weight was verified. Earthworms were classified as dead when they did not respond to a gentle mechanical stimulus. The same experiment was performed using the IC photoproducts at $80 \mathrm{mgL}^{-1}$ and different degradation times $(60,120,180$, and $300 \mathrm{~min})$ in the presence of $\mathrm{TiO}_{2}\left(0.1 \mathrm{gL}^{-1}\right)$ suspensions.

\section{Results and Discussion}

3.1. Effect of Catalyst Amount. The effect of $\mathrm{TiO}_{2}$ amount on the photocatalytic degradation of IC was studied, and results are shown in Figure 2. The significance of adsorption on the catalyst surface was evaluated from results obtained in the absence of light. The IC adsorption on $\mathrm{TiO}_{2}$ was about

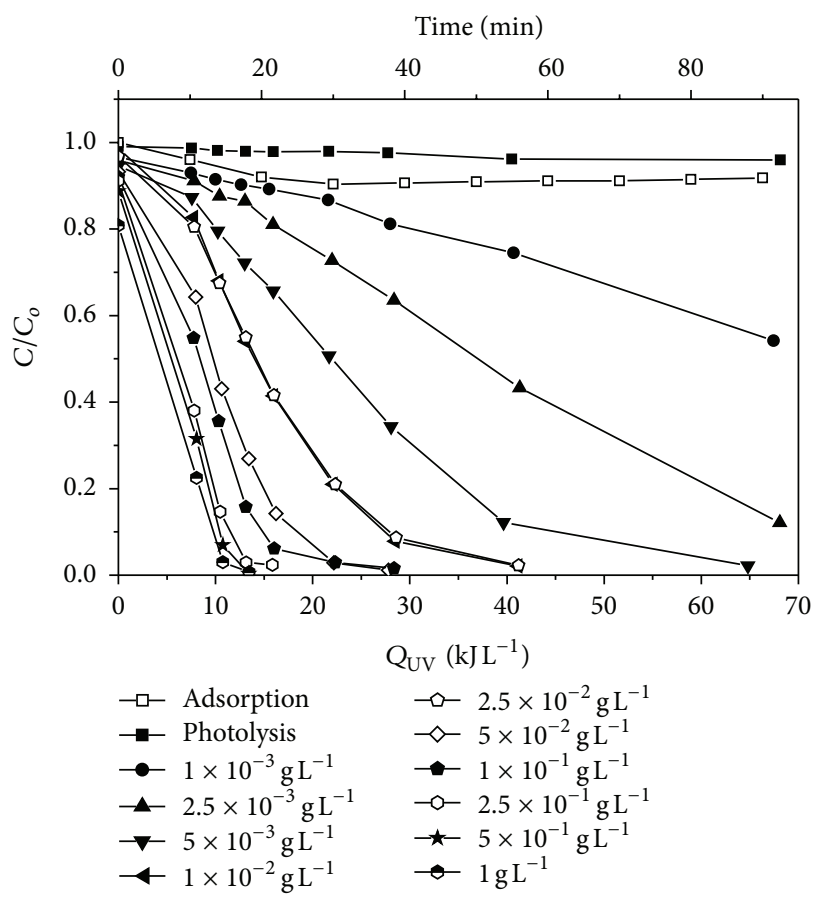

FIGURE 2: Effect of $\mathrm{TiO}_{2}$ suspension concentration on the photocatalytic degradation of $30 \mathrm{mgL}^{-1}$ of IC.

$10 \%$ after 90 min of contact and adsorption/desorption equilibrium time was $30 \mathrm{~min}$ in the dark. The color disappearance of the IC solutions was associated with cleavage of indigoid linkage in the dye molecule. Indigoids dyes are characterized by carbon to carbon double bonds $(-\mathrm{C}=\mathrm{C}-$ ) that are usually attached to two-electron groups donors $(\mathrm{NH})$ and receptors (CO) (Figure 1). The color of indigoids dyes is also influenced by the presence of associated chromophores and auxochromes groups [8]. IC can be oxidized by positive hole or hydroxyl radical or reduced by electrons in the conduction band where all processes were leading to the decrease in the color of water.

The photocatalysis efficiency is apparently directly proportional to the amount of photocatalysts used, suggesting that, for the concentration interval studied, $\mathrm{TiO}_{2}$ photodegraded IC for accumulated energies between $Q_{U V} 10-$ $30 \mathrm{kJL}^{-1}$. These results can be rationalized in terms of availability of actives sites on $\mathrm{TiO}_{2}$ surface and on the light penetration for activation of $\mathrm{TiO}_{2}$ suspensions [42]. Moreover, in suspensions containing $1 \mathrm{gL}^{-1}$ of $\mathrm{TiO}_{2}$ (first-order kinetic $=$ $0.8442 \mathrm{~min}^{-1}$ ) the depth of light penetration is considerably smaller than in those containing only $0.1 \mathrm{gL}^{-1}$ of $\mathrm{TiO}_{2}$ (firstorder kinetic $\left.=0.9002 \mathrm{~min}^{-1}\right)$. However, the availability of actives sites is much higher. Additionally, agglomeration and sedimentation of $\mathrm{TiO}_{2}$ particles also occur in suspensions containing a high concentration of $\mathrm{TiO}_{2}$ [33]. In this way, the optimum amount of $\mathrm{TiO}_{2}$ has to be determined for each solution to be treated in order to avoid the unnecessary use of a catalyst in excess. In this study, the amount of $0.1 \mathrm{gL}^{-1}$ of $\mathrm{TiO}_{2}$ was considered optimum as in Jain and Sikarwar [43] where $0.12 \mathrm{gL}^{-1}$ was found to be the optimum concentration 


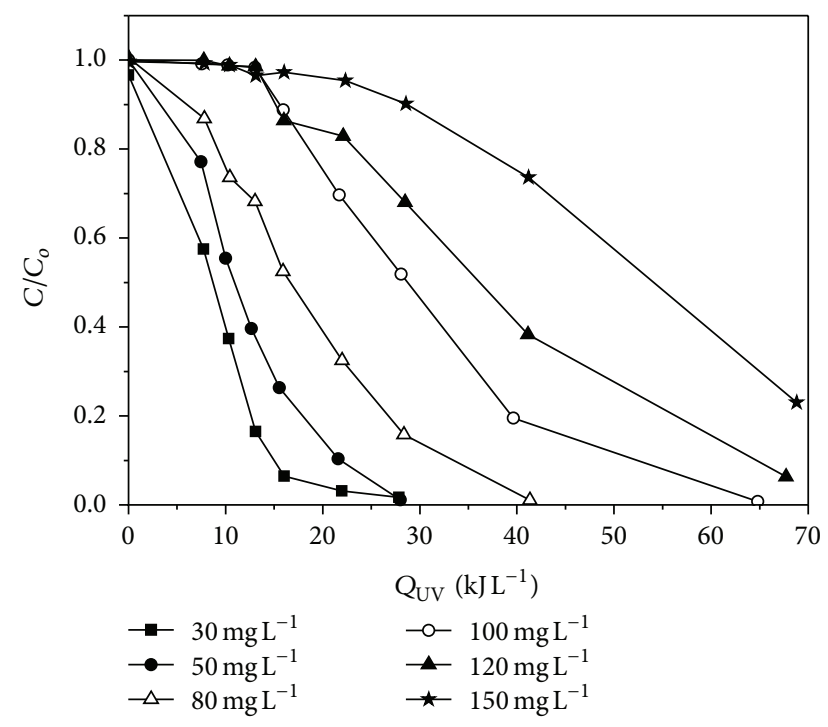

FIGURE 3: Effect of initial concentration of IC on the photocatalytic degradation with $0.1 \mathrm{gL}^{-1}$ of $\mathrm{TiO}_{2}$ suspensions.

of $\mathrm{TiO}_{2}$ for Naphthol Yellow $S$ degradation. Thus, $0.1 \mathrm{gL}^{-1}$ was employed in all subsequent experiments at laboratory level. Natarajan et al. [44] reported similar results, where they studied the degradation of Rhodamine $\mathrm{B}$ dye and utilized different amount of catalyst from 0.4 to $2.8 \mathrm{gL}^{-1}$. The results demonstrated that the percentage degradation of dye increased with the catalyst amount up to $1.6 \mathrm{gL}^{-1}$ and decreased until $2.8 \mathrm{gL}^{-1}$ from 74 to $37 \%$. Accordingly, this may be due to an increase in the turbidity of the solution, providing less UV light penetration.

3.2. Effect of Initial Dye Concentration. The effect of the dye concentration on the photodegradation efficiency is shown in Figure 3. The photocatalytic degradation of the dye decreased with increase of its concentration in the sample solution. Accumulated energy of $Q_{U V} 30 \mathrm{kJL}^{-1}$ was enough to degrade dye concentrations between 30 and $50 \mathrm{mgL}^{-1}$ whereas for $100 \mathrm{mgL}^{-1}$ it was necessary higher energy $\left(65 \mathrm{kJL}^{-1}\right)$. In the same approach, dye concentrations from 120 to $150 \mathrm{mgL}^{-1}$ on accumulated energy of $\sim 70 \mathrm{kJL}^{-1}$ were necessary. Accordingly, Ong et al. [45] investigated the degradation of two azo dyes $\left(10\right.$ to $\left.50 \mathrm{mg} \mathrm{L}^{-1}\right)$ under $6 \mathrm{~h}$ solar light irradiation and found the reaction rates were slower with higher dye concentration. The decrease of the photodegradation rate constant can be attributed to adsorption of dye molecules on the catalyst surface, and consequent reduction on the generation of $\mathrm{OH}^{*}$ radicals since the active sites were occupied by dye cations [3]. In addition, a significant amount of light may be absorbed by the indigo dye rather than $\mathrm{TiO}_{2}$. Probably reducing the efficiency of the catalytic reaction, therefore, the concentration of oxidant species decreases [15, 46]. Another possible cause in the decline of decolorization is the competition between intermediate products formed in photocatalytic processes for the limited adsorption and catalytic site on the surface of $\mathrm{TiO}_{2}$ [47].

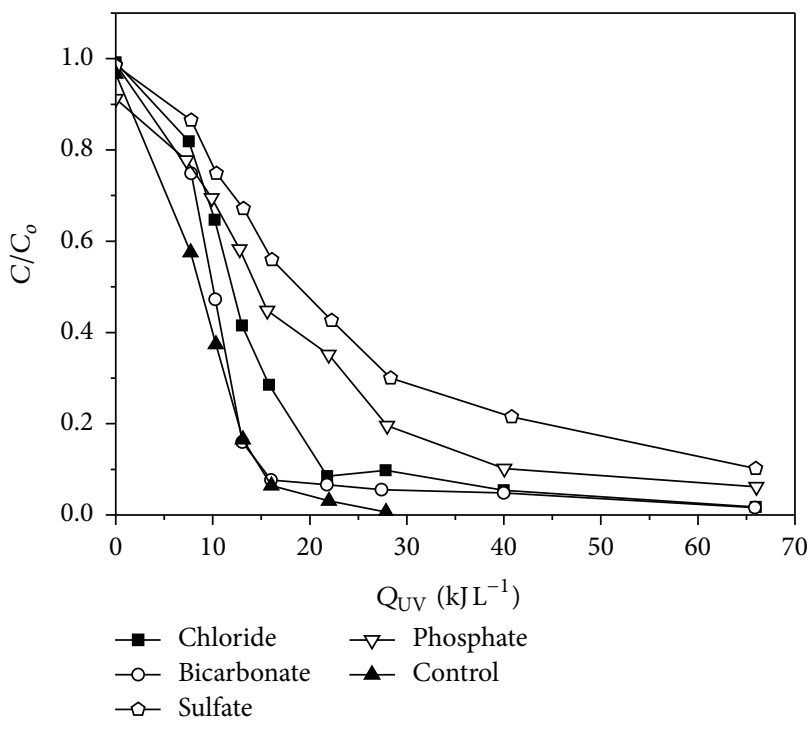

FIGURE 4: Effect of inorganic anions $(2.5 \mathrm{mM})$ on decolorization of IC $\left(30 \mathrm{mgL}^{-1}\right)$ with $0.1 \mathrm{gL}^{-1} \mathrm{TiO}_{2}$ suspensions.

3.3. Effect of Inorganic Anions. The influence of some common inorganic ions on chemical yield of the photocatalytic degradation of IC was studied. Several anions commonly used in dye-containing industrial wastewater like $\mathrm{Cl}^{-}$, $\mathrm{HCO}_{3}{ }^{-}, \mathrm{SO}_{4}{ }^{-2}$, and $\mathrm{HPO}_{4}{ }^{-2}$ were tested. These anions were applied at $2.5 \mathrm{mM}$ in $\mathrm{TiO}_{2}$ suspensions $\left(0.1 \mathrm{gL}^{-1}\right)$ in the presence of IC $\left(30 \mathrm{mgL}^{-1}\right)$ and the obtained results are shown in Figure 4. Dissolved inorganic ions may compete for the active sites on the $\mathrm{TiO}_{2}$ surface or deactivate the photocatalyst and, subsequently, decrease the degradation efficiency [15]. In the same approach, Chen et al. [48] found that the addition of $\mathrm{H}_{2} \mathrm{PO}_{4}$ and $\mathrm{HCO}_{3}$ significantly inhibited the degradation of Acid Orange 7 in the $\mathrm{TiO}_{2}$ system. In this case, the inhibition of IC decolorization was

$$
\mathrm{HCO}_{3}{ }^{-}<\mathrm{Cl}^{-}<\mathrm{HPO}_{4}{ }^{-2}<\mathrm{SO}_{4}{ }^{-2}
$$

Inhibition effect of anions can be explained as the reaction of positive holes $\left(\mathrm{h}_{\mathrm{vb}}{ }^{+}\right)$and resulting from the high reactivity and nonselectivity of hydroxyl radicals towards nontarget compounds present in the water matrix [26]. The $\mathrm{HCO}_{3}{ }^{-}$and $\mathrm{Cl}^{-}$ions were with less inhibition effect on IC decolorization. In $\mathrm{TiO}_{2} / \mathrm{UV}$ system, $\mathrm{HCO}_{3}{ }^{-}$can trap hydroxyl radicals to produce $\mathrm{CO}_{3}{ }^{-}$, which is less reactive [49]. This reaction appears to be of minor importance on the photodegradation of the IC. Additionally, in the case of $\mathrm{Cl}^{-}$under neutral or alkaline conditions, the addition of $\mathrm{Cl}^{-}$ion did not influence the reaction [50]. On the other hand, the $\mathrm{SO}_{4}{ }^{-2}$ ions demonstrated more inhibition decolorization rate since it has high competitive adsorption of the dye on the $\mathrm{TiO}_{2}$ surface and can both trap positive holes $\left(\mathrm{h}^{+}\right)$and hydroxyl radical $\left(\mathrm{OH}^{*}\right)$ [50].

3.4. Effect of Temperature. Figure 5 shows the effect of the temperature on the complete degradation of indigo carmine dye. Tests were performed at working temperature in 


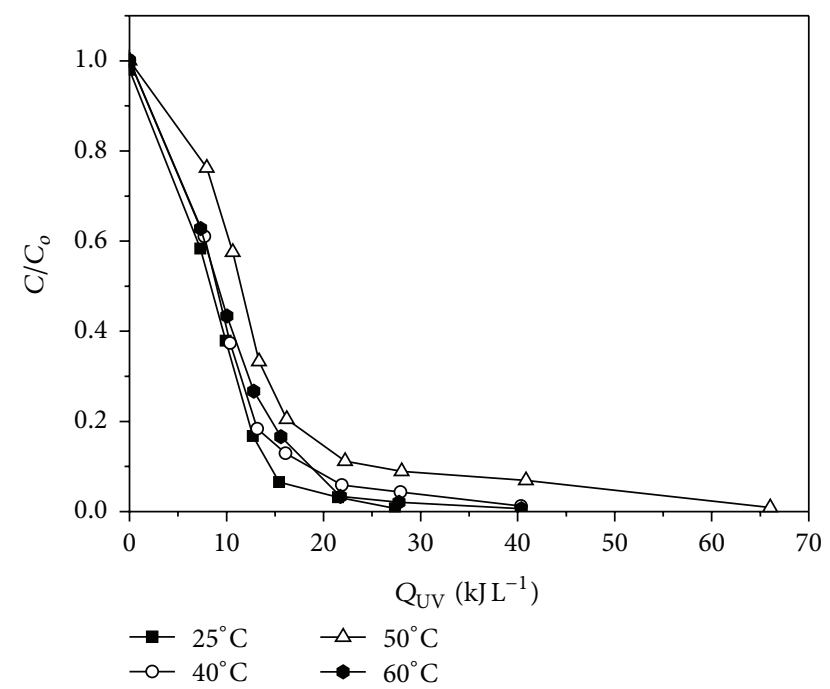

FIGURE 5: Effect of temperature on decolorization of IC $\left(30 \mathrm{mgL}^{-1}\right)$ with $0.1 \mathrm{gL}^{-1} \mathrm{TiO}_{2}$ suspensions.

the range of $25-60^{\circ} \mathrm{C}$. The results indicate that the rate of the photodegradation is temperature dependent, and it decays with the rise of solution temperature. It is known that an increase in temperature can affect the efficiency of $\mathrm{e}^{-} / \mathrm{h}^{+}$recombination and adsorption/desorption processes of dyes molecules on the $\mathrm{TiO}_{2}$ photocatalyst surface [51]. Some of the most important surface phenomena are dye molecule aggregation, tautomerization, and geometric (cis-trans) isomerization and all those processes can be affected by temperature variation. The increase of solution temperature causes disaggregation of the dye molecules [42]. Habibi et al. [42] considered molecular weight and anion site (sulfate and a carboxylic group) of three azo dyes, which can interact with molecules by iondipole interactions. According to these authors the dye (C.I Reactive Yellow 2) has low molecular weight (M.W. = $872.5 \mathrm{gmol}^{-1}$ ), less anionic sites (three sulfate groups), and significant variation of hydration when compared with other dyes. Consequently, variation of temperature solution has a significant effect on the effective collisions between dyes and $\mathrm{TiO}_{2}$ photocatalyst. In this case, the IC molecules possess a comparatively low molecular weight (M.W. $=466.36 \mathrm{gmol}^{-1}$ ) and only two anion sites (sulfate groups). As a consequence, the variation of the temperature should also affect its photodegradation as observed.

3.5. Effect of Hydrogen Peroxide Addition. The principal problem found in most photocatalysis processes using $\mathrm{TiO}_{2}$ is the undesired electron/hole recombination, which represents the major energy-wasting step thus restricting the feasible quantum yield. Hydrogen peroxide is an electron donor favoring the photocatalytic process inhibiting electron-hole recombination [52]. In this sense, the effect of $\mathrm{H}_{2} \mathrm{O}_{2}$ on the photocatalytic degradation of IC was examined. It was noted that when the hydrogen peroxide concentration increases, the photodegradation suffers an initial increase up to $\mathrm{H}_{2} \mathrm{O}_{2}$

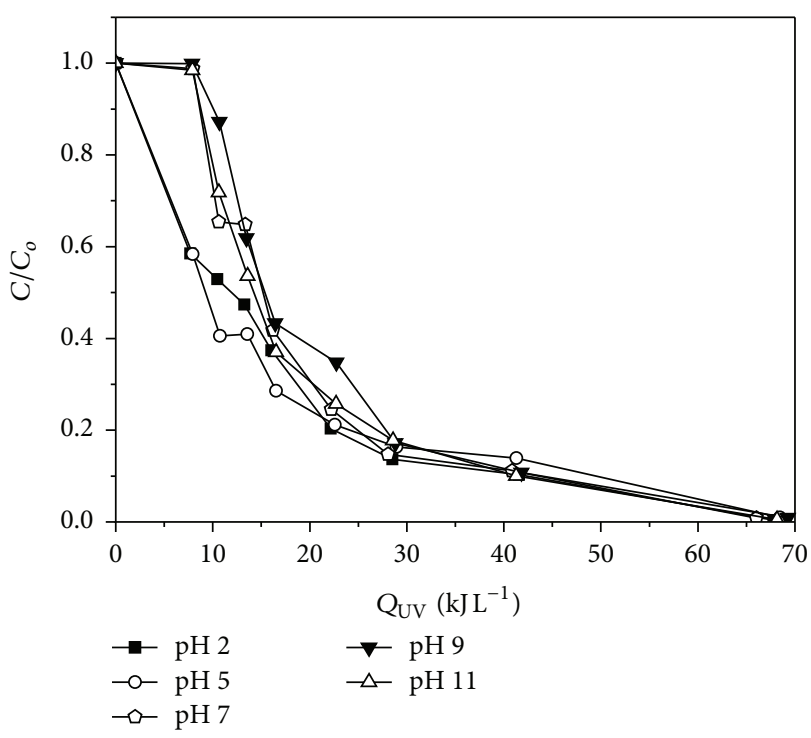

FIGURE 6: Photodegradation of IC $\left(30 \mathrm{mgL}^{-1}\right)$ by $\mathrm{TiO}_{2}\left(0.1 \mathrm{gL}^{-1}\right)$ at different $\mathrm{pH}$ values.

concentration equal to $0.022 \mathrm{M}$ and a decrease at higher concentrations (data not shown). Hydrogen peroxide at low concentration acts mainly as a source of hydroxyl radicals and as an electron scavenger inhibiting the electron-hole recombination [53]:

$$
\mathrm{H}_{2} \mathrm{O}_{2}+\mathrm{e}_{\mathrm{CB}}^{-} \longrightarrow \mathrm{OH}^{\bullet}+\mathrm{OH}^{-}
$$

However, at higher concentrations, $\mathrm{H}_{2} \mathrm{O}_{2}$ reacts with hydroxyl radicals and acts itself as a scavenger of the photoproduced holes. The $\mathrm{H}_{2} \mathrm{O}_{2}$ excess acts with a self-quenching process of $\mathrm{OH}^{*}$ to form hydroperoxyl radicals $\left(\mathrm{OOH}^{*}\right)(6)$ in which the oxidation potential is much lower than that of $\mathrm{OH}^{\circ}$, [54] leading to a decrease in the photocatalytic efficiency:

$$
\mathrm{H}_{2} \mathrm{O}_{2}+{ }^{\circ} \mathrm{OH} \longrightarrow \mathrm{H}_{2} \mathrm{O}+{ }^{\circ} \mathrm{OOH}
$$

Similar results were reported by Gemeay et al. [55] who found the first-order dependence at lower concentration of $\mathrm{H}_{2} \mathrm{O}_{2}$, while at higher $\mathrm{H}_{2} \mathrm{O}_{2}$ dosage the reaction order decreases, reaching almost zero on kinetic heterogeneous photocatalysis. The optimum dosage of $\mathrm{H}_{2} \mathrm{O}_{2}$ is variable and has been reported that it was dependent on initial dye concentration [56]. Thus, Pang and Abdullah [54] determined the optimum dosage of $\mathrm{H}_{2} \mathrm{O}_{2}$ was about $40 \mathrm{mM}$ for real textile wastewater photodegradation by $\mathrm{TiO}_{2}$ nanotubes.

3.6. Effect of Initial pH. The effect of $\mathrm{pH}$ changes on the photodegradation rate was also studied in the range from $\mathrm{pH} 2$ to $\mathrm{pH} 11$ (Figure 6). The photocatalytic reaction occurs on the surface of catalyst and is dependent on charged surface of $\mathrm{TiO}_{2}$. In this way, the adsorptive properties of $\mathrm{TiO}_{2}$ particles depended strongly on the solution $\mathrm{pH}$ [57]. The degradation of indigo carmine was faster in acids solution (i.e., $\mathrm{pH}$ range from 2 to 5). In neutral and basic medium, the rate of dye degradation was slow; nevertheless, in accumulated energy of 


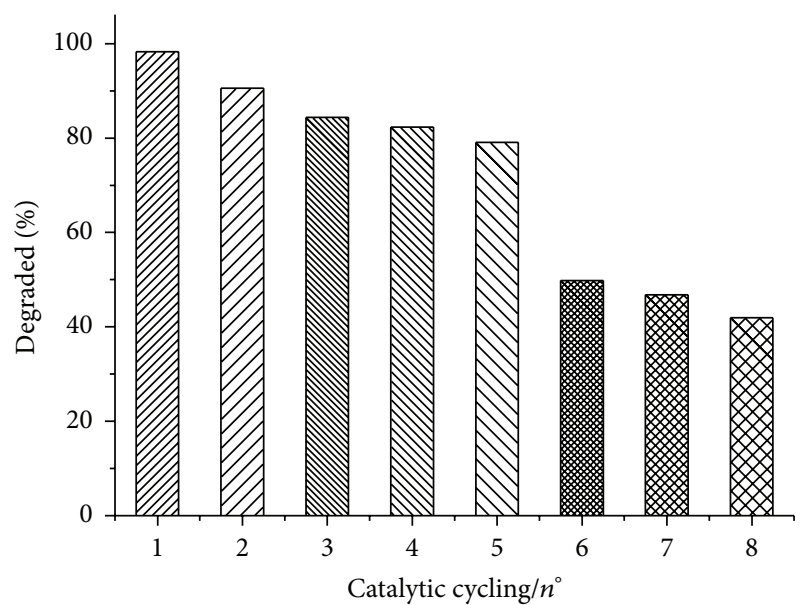

Figure 7: Recycling and reuse of $0.1 \mathrm{gL}^{-1}$ of $\mathrm{TiO}_{2}$ on the photocatalytic degradation of $30 \mathrm{mgL}^{-1}$ of IC for an accumulated energy, $Q_{\mathrm{UV}}$ of $15 \mathrm{kJL}^{-1}$.

$Q_{U V} 70 \mathrm{kJL}^{-1}$ all IC solutions were degraded. This effect can be explained by the surface charge density of $\mathrm{TiO}_{2}$. The point of zero charge (pzc) of $\mathrm{TiO}_{2}$ is at $\mathrm{pH}=6.8$. Thus, the $\mathrm{TiO}_{2}$ surface is fully protonated in acidic medium solution and negatively charged under alkaline conditions [58]:

$$
\begin{gathered}
\mathrm{pH}<\mathrm{pzc}: \mathrm{TiOH}+\mathrm{H}^{+} \Longleftrightarrow \mathrm{TiOH}_{2}^{+} \\
\mathrm{pH}>\text { pzc: } \mathrm{TiOH}+\mathrm{OH}^{-} \Longleftrightarrow \mathrm{TiO}^{-}+\mathrm{H}_{2} \mathrm{O}
\end{gathered}
$$

Considering the IC structure has sulphuric groups, which is negatively charged, at $\mathrm{pH}<5.0$ the positive charge via protonation (7) in the photocatalyst surface promotes active interaction of a dye onto catalyst surface and improves the photocatalytic degradation. Othman et al. [59] obtained similar results with the decolorization efficiencies increased with decreasing $\mathrm{pH}$ values, where, at $\mathrm{pH}>3$, the decolorization of the IC was negligible. On the order hand, in the basic solutions $(\mathrm{pH}>\mathrm{pzc})$ the surface of the catalyst is negatively charged via the proton abstraction by hydroxide ion (Equation (8)). Consequently, repulsions between negative-charged surface of the catalyst and anionic dye fragments retard the surface adsorption, making low photodegradation activity [60]. In the same approach, Sriwong et al. [61] described the order of activity decreases as $\mathrm{pH} 3>\mathrm{pH} 5>\mathrm{pH} 6.53>\mathrm{pH} 8$ in thin rubber sheet embedded with $\mathrm{TiO}_{2}$ for IC degradation.

3.7. Recycling of $\mathrm{TiO}_{2}$. One of today's main industrial wastewater treatment strategies is focused on the development of green technologies and management practices for environmental benefit. To attend this "new" concept, the recycling of the photocatalyst was performed (Figure 7). The $\mathrm{TiO}_{2}$ catalyst was recycled for consecutively reuse on this procedure up to 8 times. The recycling studies were conducted with $0.1 \mathrm{gL}^{-1}$ of the catalyst, and the efficiency of the photodegradation process was evaluated and compared with the consecutive cycles. According to the results, the effectiveness of the $\mathrm{TiO}_{2}$ decreased from $98 \%$ (first cycle) to $80 \%$ (5th cycle) and subsequently to $50 \%$ (6th cycle on). However, the rate of degradation was kept significant even after eight cycles of $\mathrm{TiO}_{2}$ reuse. The effectiveness of complete separation of photocatalysts from treated water is a critical step required to keep a satisfactory degradation [62].

The harm photocatalyst effectiveness can be caused by the material loss during the recovering procedure, once it was very slow and not efficient. Costa and Prado [63] studied the recyclable of $\mathrm{TiO}_{2}$ nanotubes and anatase for IC photodegradation. They found that the filtration of $\mathrm{TiO}_{2}$ nanotubes was very quick and easy maintaining $90 \%$ of dye degradation after 10 catalytic cycles. On the order hand, the filtration of $\mathrm{TiO}_{2}$ anatase was very inefficient, and activity decreased dramatically to $10 \%$ after 10 cycles. Moreover, agglomeration and sedimentation of IC around $\mathrm{TiO}_{2}$ particles after each cycle of photocatalytic degradation are a possible cause of the observed decrease in its efficiency [64].

This study further shows that the reuse of the $\mathrm{TiO}_{2}$ presents a promising photocatalytic performance with little variation of decay rate after eight consecutive usages and also high photochemical stability.

3.8. Solar CPC Photocatalytic Degradation Using $\mathrm{TiO}_{2} \mathrm{Sup}$ ported on Glass Spheres. Solar CPC reactor using $\mathrm{TiO}_{2}$ supported on glass spheres was evaluated on degradation of IC $\left(30 \mathrm{mgL}^{-1}\right)$ in different water matrices. Previously in [32], it was demonstrated the effectiveness of using $\mathrm{TiO}_{2}$ supported on glass spheres towards acetaminophen.

The solar CPC pilot plant photocatalytic activity of supported $\mathrm{TiO}_{2}$ in different water matrices in the degradation of indigo carmine dye is shown in Figure 8(a) (see conditions in Section 2.4). These results showed a strong influence of the matrix on photocatalytic degradation of the dye. Thus, in distilled water IC was completely degraded after $Q_{U V}$ of $11 \mathrm{kJL}^{-1}$. On the other hand, for synthetic freshwater the energy needed it was observed to be slightly longer $\left(\sim 17 \mathrm{kJL}^{-1}\right)$ for total degradation. Probably, this is due to synthetic freshwater composition and to the fact that some of the ions present in it have an adverse effect on the photocatalytic degradation of IC as discussed above. When an even more complex water matrix was utilized, the system efficacy on IC degradation apparently decreases. After a $Q_{U V}$ of $17 \mathrm{kJL}^{-1}, 32 \%$ and $37 \%$ of the contaminant remain in solution when the synthetic and real MWWTP secondary effluents were used, respectively. Achieved complete degradation of the dye with $Q_{U V}$ of 36 and $42 \mathrm{kJL}^{-1}$ for both matrices, respectively. This fact can be explained due to the presence of different substances in the water matrix (see Table 1), like carbonate, $\mathrm{CO}_{3}{ }^{-2}$, which is generally found in wastewater in high concentrations [65], which can be absorbed onto the catalyst surface (blocking and/or competing for the reaction) and/or $\mathrm{OH}^{\bullet}$ scavenger.

Other results [66] obtained at the solar CPC photocatalytic degradation of IC using $\mathrm{TiO}_{2}$ slurry for treatment of real MWWTP secondary effluent demonstrated greater efficiency of this procedure when compared under the same conditions with supported $\mathrm{TiO}_{2}$. Probably, this would indicate that the catalyst coated on glass spheres is not fully illuminated. Indeed, there are large amounts of $\mathrm{TiO}_{2}$ particles inside the CPC tube, and a considerable amount of $\mathrm{TiO}_{2}$ 


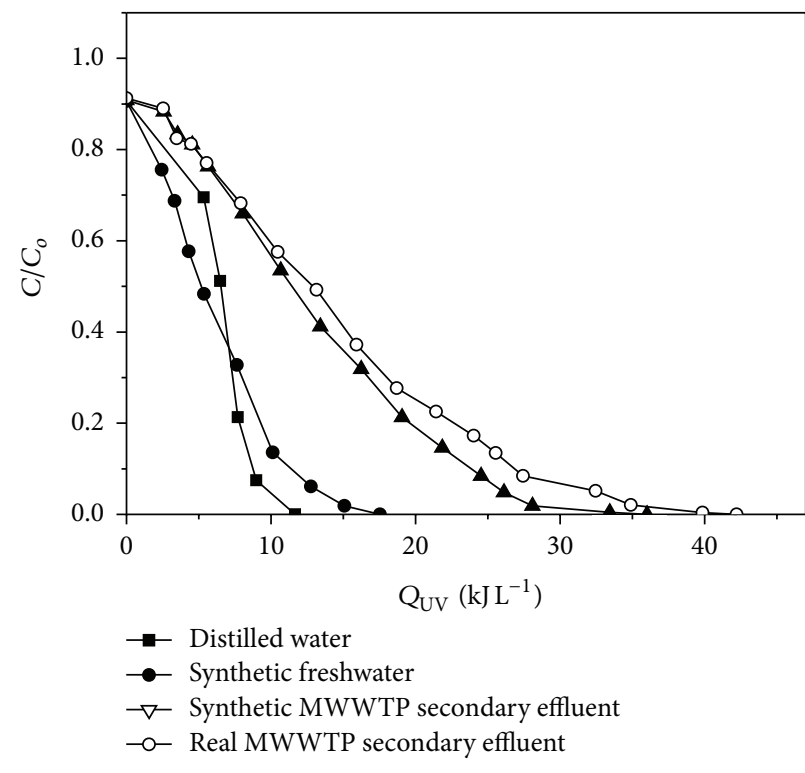

(a)

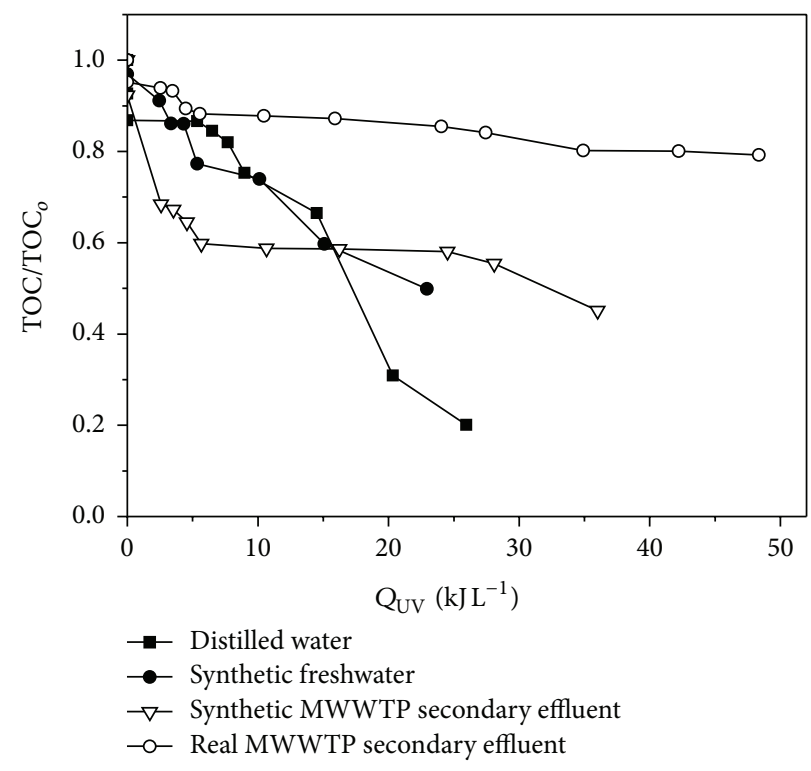

(b)

FIGURE 8: Solar CPC photodegradation of $30 \mathrm{mgL}^{-1}$ of IC for different water matrices mediated $\mathrm{TiO}_{2}$ supported on glass spheres: (a) IC concentration and (b) TOC evaluation.

supported on glass spheres having some sites not activated for photocatalysis and lower area surface of the catalyst. However, supported $\mathrm{TiO}_{2}$ has the enormous advantage of eliminating the catalyst removal step and thus considerably reducing the costs of treatment.

It should be emphasized that the decline of the IC solutions does not provide complete data on the indigo carmine dye degradation. Therefore, other parameters such as TOC, ions $\left(\mathrm{SO}_{4}{ }^{2-}\right.$ and $\left.\mathrm{NH}_{4}{ }^{+}\right)$, carboxylic acids were monitored. Figure $8(\mathrm{~b})$ presents the effectiveness of mineralization of indigo carmine determined on the basis of changes in TOC concentration. The significant TOC decrease was observed only in distilled water; for other complexes matrices the mineralization was not so efficient. The real MWWTP secondary effluent (initial TOC $26.9 \mathrm{mgL}^{-1}$ ) photooxidation with $\mathrm{TiO}_{2}$ reduced TOC concentration to $\sim 6 \mathrm{mgL}^{-1}$. This water contained high concentrations of inorganic carbons $\left(69.92 \mathrm{mgL}^{-1}\right)$ which promoted the decrease of the activity of $\mathrm{OH}^{*}$ radicals. The TOC decrease suggests that the irradiation processes of supported $\mathrm{TiO}_{2}$ of a large number of lower molecular weight compounds are formed. Further, hydroxylation of aromatic reaction products leads to cleavage of the aromatic ring, resulting in the formation of oxygencontaining aliphatic compounds $[67,68]$. On the other hand, after the fading stage, breakdown of carbon-to-carbon double bond of IC may form inorganic ions.

The results on the intermediate organic acids and $\mathrm{SO}_{4}{ }^{2-}$ and $\mathrm{NH}_{4}{ }^{+}$ions generated while the degradation process was analyzed by ion chromatography are shown in Figure 9. Formate, acetate, and oxalate were detected during degradation in real MWWTP secondary effluent containing IC as shown in Figure 9(a). The evolution of $\mathrm{SO}_{4}{ }^{-2}$ and $\mathrm{NH}_{4}{ }^{+}$ions is presented in Figure 9(b). The structure of indigo carmine dye has two sulfonic groups attached to two aromatic rings and these results indicate that $\mathrm{SO}_{4}{ }^{-2}$ ions are formed during the process. The evolution of $\mathrm{NH}_{4}{ }^{+}$suggests that this ion is the primary $\mathrm{N}$-containing mineralization product and $\mathrm{SO}_{4}{ }^{-2}$ are not observed at a delay time. It indicates its origin as first products resulted from the initial attack on the carbon-tocarbon double bond of IC.

3.9. Ecotoxicity Test with Eisenia andrei Earthworms. Effects of different IC concentration and its photoproducts on earthworms were studied. In all cases, no mortality was observed. Biomass loss was observed at all concentrations when compared to control (see Figure 10(a)). However, no significant difference $(P>0.05)$ of a reduction in mean weight earthworms was found from the paper treated with different concentrations of IC. Toxicity tests with earthworms were also carried out for the photodegradation products of IC, and no mortality was observed after $24 \mathrm{~h}$ exposure to different treatments. The effect on the reduction of weight can be shown in Figure 10(b). The difference of masses found between initial time $(t=0 \mathrm{~min}$ ) and $24 \mathrm{~h}$ of exposure did not show significant difference according to ANOVA analysis $(P>0.05)$, for control and all photodegradation times (60, $120,180$, and $300 \mathrm{~min})$. These results suggest that the presence of IC and its photoproducts demonstrated no effect on the earthworms for acute contact test $(24 \mathrm{~h})$. However, more tests must be performed for better availability of the IC toxicity for Eisenia andrei.

\section{Conclusions}

Photocatalytic degradation of indigo carmine dye in the presence of titanium dioxide was performed under different 


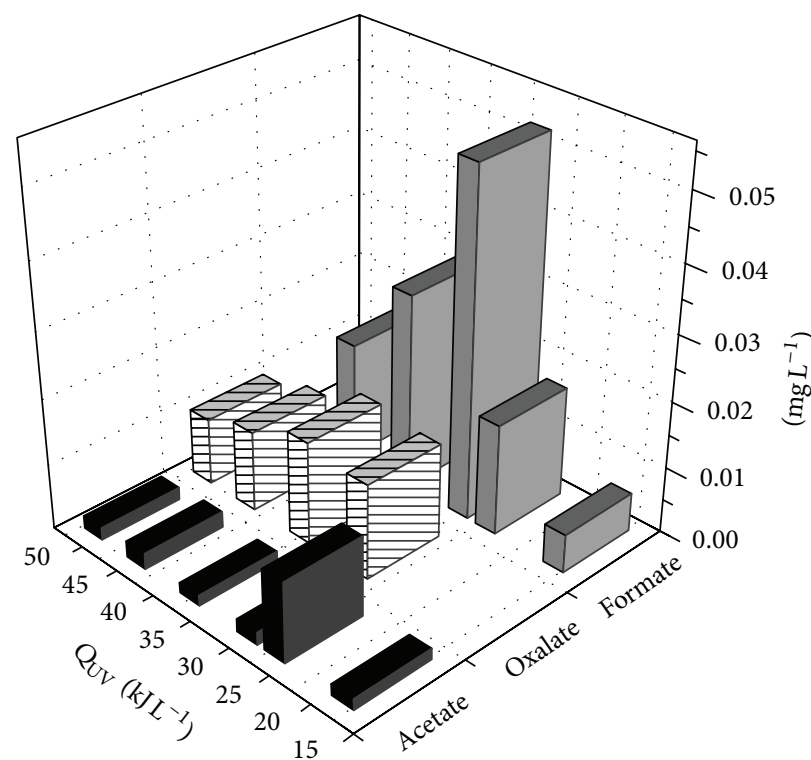

(a)

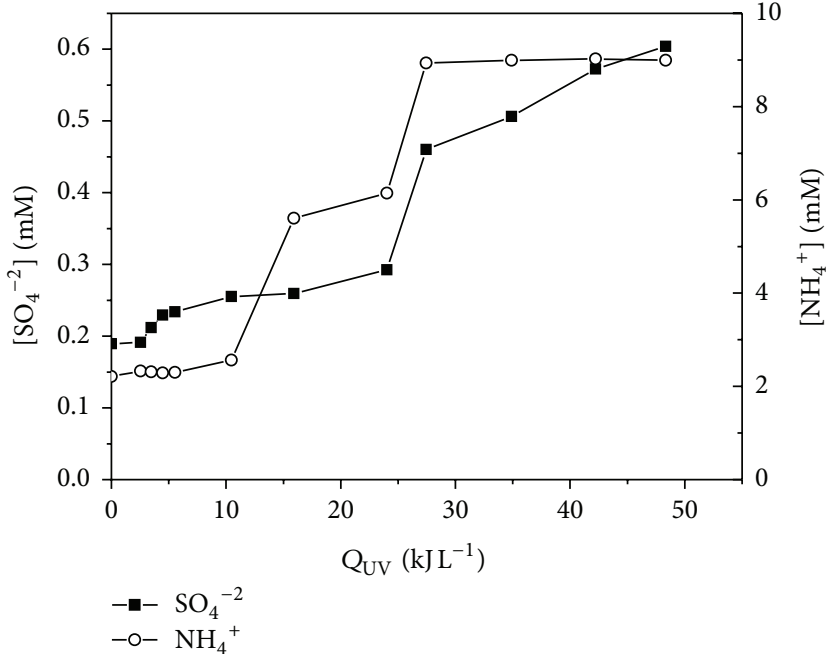

(b)

FIGURE 9: Evaluation of the concentrations of (a) carboxylic acids and (b) $\mathrm{SO}_{4}{ }^{-2}$ and $\mathrm{NH}_{4}{ }^{+}$ions, followed by ion chromatography, formed during solar CPC photodegradation of $30 \mathrm{mgL}^{-1} \mathrm{IC}$ with supported $\mathrm{TiO}_{2}$ in real $\mathrm{MWWTP}$ secondary effluent.

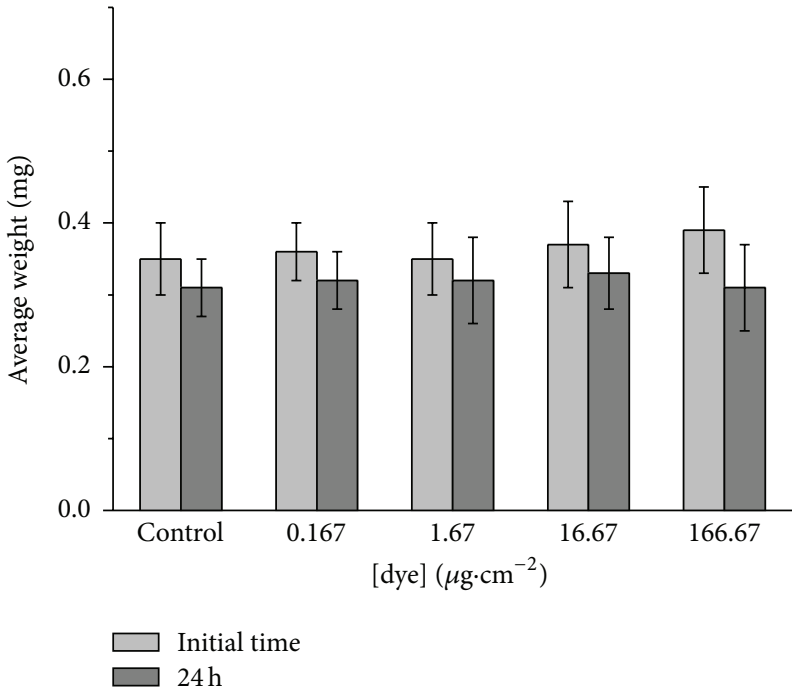

(a)

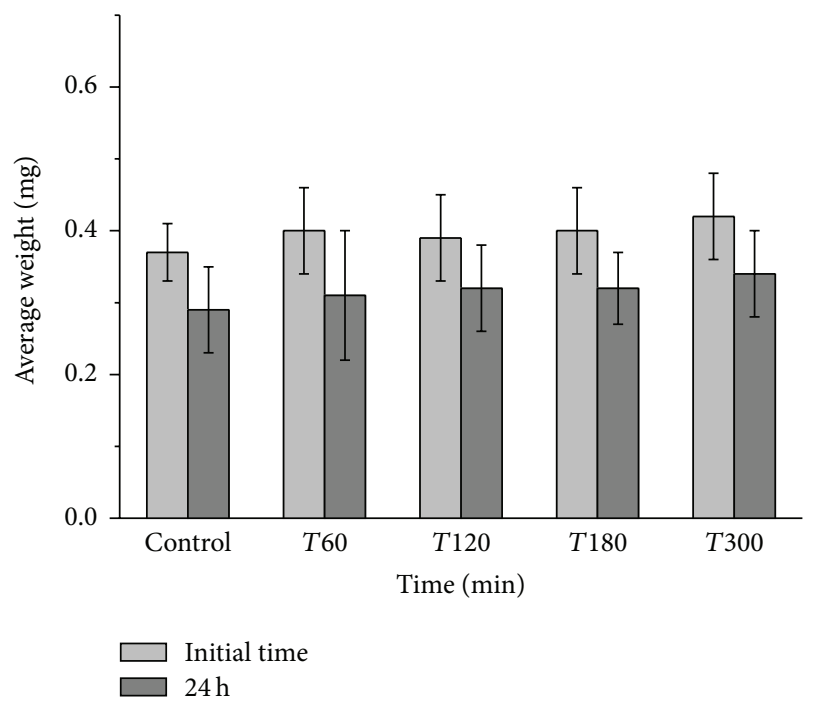

(b)

FIGURE 10: Acute ecotoxicology test by Eisenia andrei earthworms: (a) different initial IC concentrations and (b) IC ( $\left.80 \mathrm{mgL}^{-1}\right)$ photoproducts at different times.

conditions. Results indicated that the photocatalytic degradation of IC in water with powdered $\mathrm{TiO}_{2}$ depends on various parameters, as the concentration of dye, amount of photocatalyst, presence of inorganic anions, solution $\mathrm{pH}$, temperature, and hydrogen peroxide. It was found that the optimal amount of catalysts to be used was $0.1 \mathrm{gL}^{-1}$. Concerning the different initial dye concentration, it caused a significant absorption of light that led to a decrease in photodegradation. Several inorganic anions were tested competing for the active sites on the $\mathrm{TiO}_{2}$ surface. The temperature demonstrated being dependent on disfavoring IC removal.

The photodegradation is favored in acidic solution. The recycling of $\mathrm{TiO}_{2}$ can be performed with the photocatalyst being able to be adequately used in other reactions. $\mathrm{A} \mathrm{TiO}_{2}$ catalyst supported on glass spheres proved having high efficiency to remove IC in different water matrices. However, the strong influence of the water matrix on IC photocatalytic degradation was also demonstrated. The IC acute toxicity test 
$(24 \mathrm{~h})$ and its photoproducts demonstrated no effect on the earthworms.

\section{Conflict of Interests}

The authors declare that there is no conflict of interests regarding the publication of this paper.

\section{Acknowledgments}

Enrico Mendes Saggioro thanks ENSP/FIOCRUZ and Ciência sem Fronteiras for scholarship and Plataforma Solar de Almería. Josino Costa Moreira thanks Faperj and CNPq. Margarita Jiménez would like to acknowledge the granted scholarship of CONACyT (Consejo Nacional de Ciencia y Tecnología, México). The authors thank P. C. G. Pereira for the assistance with ecotoxicological tests.

\section{References}

[1] N. Barka, A. Assabbane, A. Nounah, and Y. A. Ichou, "Photocatalytic degradation of indigo carmine in aqueous solution by $\mathrm{TiO}_{2}$-coated non-woven fibres," Journal of Hazardous Materials, vol. 152, no. 3, pp. 1054-1059, 2008.

[2] Z. Zainal, L. K. Hui, M. Z. Hussein, Y. H. Taufiq-Yap, A. H. Abdullah, and I. Ramli, "Removal of dyes using immobilized titanium dioxide illuminated by fluorescent lamps," Journal of Hazardous Materials, vol. 125, no. 1-3, pp. 113-120, 2005.

[3] C.-C. Wang, C.-K. Lee, M.-D. Lyu, and L.-C. Juang, "Photocatalytic degradation of C.I. Basic Violet 10 using $\mathrm{TiO}_{2}$ catalysts supported by Y zeolite: an investigation of the effects of operational parameters," Dyes and Pigments, vol. 76, no. 3, pp. 817-824, 2008.

[4] T. Robinson, G. McMullan, R. Marchant, and P. Nigam, "Remediation of dyes in textile effluent: a critical review on current treatment technologies with a proposed alternative," Bioresource Technology, vol. 77, no. 3, pp. 247-255, 2001.

[5] M. A. Behnajady, N. Modirshahla, N. Daneshvar, and M. Rabbani, "Photocatalytic degradation of an azo dye in a tubular continuous-flow photoreactor with immobilized $\mathrm{TiO}_{2}$ on glass plates," Chemical Engineering Journal, vol. 127, no. 1-3, pp. 167176, 2007.

[6] A. Andreotti, I. Bonaduce, M. P. Colombini, and E. Ribechini, "Characterisation of natural indigo and shellfish purple by mass spectrometric techniques," Rapid Communications in Mass Spectrometry, vol. 18, no. 11, pp. 1213-1220, 2004.

[7] A. S. Oliveira, E. M. Saggioro, N. R. Barbosa, A. Mazzei, L. F. V. Ferreira, and J. C. Moreira, "Surface photocatalysis: a study of the thickness of $\mathrm{TiO}_{2}$ layers on the photocatalytic decomposition of soluble indigo blue dye," Revista de Chimie, vol. 62, no. 4, pp. 462-468, 2011.

[8] M. Vautier, C. Guillard, and J. M. Herrmann, "Photocatalytic degradation of dyes in water: case study of indigo and of indigo carmine," Journal of Catalysis, vol. 201, no. 1, pp. 46-59, 2001.

[9] C. L. Jenkins, “Textile dyes are potential hazards," Archives of Environmental Health, vol. 40, no. 5, pp. 7-12, 1978.

[10] M. A. Sanromán, M. Pazos, M. T. Ricart, and C. Cameselle, "Electrochemical decolourisation of structurally different dyes," Chemosphere, vol. 57, no. 3, pp. 233-239, 2004.
[11] T. Sano, E. Puzenat, C. Guillard, C. Geantet, and S. Matsuzawa, "Degradation of $\mathrm{C}_{2} \mathrm{H}_{2}$ with modified- $\mathrm{TiO}_{2}$ photocatalysts under visible light irradiation," Journal of Molecular Catalysis A: Chemical, vol. 284, no. 1-2, pp. 127-133, 2008.

[12] A. R. Khataee, V. Vatanpour, and A. R. Amani Ghadim, "Decolorization of C.I. Acid Blue 9 solution by UV/Nano$\mathrm{TiO}_{2}$, Fenton, Fenton-like, electro-Fenton and electrocoagulation processes: a comparative study," Journal of Hazardous Materials, vol. 161, no. 2-3, pp. 1225-1233, 2009.

[13] J. Zhao, T. Wu, K. Wu, K. Oikawa, H. Hidaka, and N. Serpone, "Photoassisted degradation of dye pollutants. 3. Degradation of the cationic dye rhodamine $\mathrm{B}$ in aqueous anionic surfactant $/ \mathrm{TiO}_{2}$ dispersions under visible light irradiation: evidence for the need of substrate adsorption on $\mathrm{TiO}_{2}$ particles," Environmental Science and Technology, vol. 32, no. 16, pp. 23942400, 1998.

[14] G. Liu, T. Wu, J. Zhao, H. Hidaka, and N. Serpone, "Irreversible degradation of Alizarin Red under visible light radiation in airequilibrated aqueous $\mathrm{TiO}_{2}$ dispersions," Environmental Science and Technology, vol. 33, no. 12, pp. 2081-2087, 1999.

[15] I. K. Konstantinou and T. A. Albanis, " $\mathrm{TiO}_{2}$-assisted photocatalytic degradation of azo dyes in aqueous solution: kinetic and mechanistic investigations: a review," Applied Catalysis B: Environmental, vol. 49, no. 1, pp. 1-14, 2004.

[16] A. Fujishima, T. N. Rao, and D. A. Tryk, "Titanium dioxide photocatalysis," Journal of Photochemistry and Photobiology C: Photochemistry Reviews, vol. 1, no. 1, pp. 1-21, 2000.

[17] C. Chen, Z. Wang, S. Ruan, B. Zou, M. Zhao, and F. Wu, "Photocatalytic degradation of C.I. Acid Orange 52 in the presence of $\mathrm{Zn}$-doped $\mathrm{TiO}_{2}$ prepared by a stearic acid gel method," Dyes and Pigments, vol. 77, no. 1, pp. 204-209, 2008.

[18] T. Aarthi, P. Narahari, and G. Madras, "Photocatalytic degradation of Azure and Sudan dyes using nano $\mathrm{TiO}_{2}$," Journal of Hazardous Materials, vol. 149, no. 3, pp. 725-734, 2007.

[19] J. Saien and A. R. Soleymani, "Degradation and mineralization of Direct Blue 71 in a circulating upflow reactor by $\mathrm{UV} / \mathrm{TiO}_{2}$ process and employing a new method in kinetic study," Journal of Hazardous Materials, vol. 144, no. 1-2, pp. 506-512, 2007.

[20] L. Andronic and A. Duta, " $\mathrm{TiO}_{2}$ thin films for dyes photodegradation," Thin Solid Films, vol. 515, no. 16, pp. 6294-6297, 2007.

[21] M. Huang, C. Xu, Z. Wu, Y. Huang, J. Lin, and J. Wu, "Photocatalytic discolorization of methyl orange solution by $\mathrm{Pt}$ modified $\mathrm{TiO}_{2}$ loaded on natural zeolite," Dyes and Pigments, vol. 77, no. 2, pp. 327-334, 2008.

[22] M. Saquib, M. Abu Tariq, M. M. Haque, and M. Muneer, "Photocatalytic degradation of disperse blue 1 using $\mathrm{UV} / \mathrm{TiO}_{2} / \mathrm{H}_{2} \mathrm{O}_{2}$ process," Journal of Environmental Management, vol. 88, no. 2, pp. 300-306, 2008.

[23] C. G. Maia, A. S. Oliveira, E. M. Saggioro, and J. C. Moreira, "Optimization of the photocatalytic degradation of commercial azo dyes in aqueous $\mathrm{TiO}_{2}$ suspensions," Reaction Kinetics, Mechanisms and Catalysis, vol. 113, no. 1, pp. 305-320, 2014.

[24] M. R. Hoffmann, S. T. Martin, W. Y. Choi, and D. W. Bahnemann, "Environmental applications of semiconductor photocatalysis," Chemical Reviews, vol. 95, no. 1, pp. 69-96, 1995.

[25] A. Fujishima and X. Zhang, "Titanium dioxide photocatalysis: present situation and future approaches," Comptes Rendus Chimie, vol. 9, no. 5-6, pp. 750-760, 2006.

[26] N. M. Mahmoodi, M. Arami, N. Y. Limaee, K. Gharanjig, and F. D. Ardejani, "Decolorization and mineralization of textile dyes at solution bulk by heterogeneous nanophotocatalysis using 
immobilized nanoparticles of titanium dioxide," Colloids and Surfaces A: Physicochemical and Engineering Aspects, vol. 290, no. 1-3, pp. 125-131, 2006.

[27] C. Guillard, J. Disdier, C. Monnet et al., "Solar efficiency of a new deposited titania photocatalyst: chlorophenol, pesticide and dye removal applications," Applied Catalysis B: Environmental, vol. 46, no. 2, pp. 319-332, 2003.

[28] M. G. Paoletti, "The role of earthworms for assessment of sustainability and as bioindicators," Agriculture, Ecosystems and Environment, vol. 74, no. 1-3, pp. 137-155, 1999.

[29] F. V. Correia and J. C. Moreira, "Effects of glyphosate and 2,4-D on earthworms (Eisenia foetida) in laboratory tests," Bulletin of Environmental Contamination and Toxicology, vol. 85, no. 3, pp. 264-268, 2010.

[30] A. Sirisuk, C. G. Hill Jr., and M. A. Anderson, "Photocatalytic degradation of ethylene over thin films of titania supported on glass rings," Catalysis Today, vol. 54, no. 1, pp. 159-164, 1999.

[31] N. Miranda-García, M. I. Maldonado, J. M. Coronado, and S. Malato, "Degradation study of 15 emerging contaminants at low concentration by immobilized $\mathrm{TiO}_{2}$ in a pilot plant," Catalysis Today, vol. 151, no. 1-2, pp. 107-113, 2010.

[32] M. Jiménez, M. Ignacio Maldonado, E. M. Rodríguez et al., "Supported $\mathrm{TiO}_{2}$ solar photocatalysis at semi-pilot scale: degradation of pesticides found in citrus processing industry wastewater, reactivity and influence of photogenerated species," Journal of Chemical Technology and Biotechnology, vol. 90, pp. 149-157, 2015.

[33] E. M. Saggioro, A. S. Oliveira, T. Pavesi, C. G. Maia, L. F. V. Ferreira, and J. C. Moreira, "Use of titanium dioxide photocatalysis on the remediation of model textile wastewaters containing azo dyes," Molecules, vol. 16, no. 12, pp. 10370-10386, 2011.

[34] M. Lapertot, C. Pulgarín, P. Fernández-Ibáñez et al., "Enhancing biodegradability of priority substances (pesticides) by solar photo-Fenton," Water Research, vol. 40, no. 5, pp. 1086-1094, 2006.

[35] L. S. Clesceriv, A. E. Greenberg, and A. D. Eaton, Standard Methods for the Examination of Water and Wastewater, American Public Health Association, Washington, DC, USA, 1998.

[36] R. Zhang, S. Vigneswaran, H. Ngo, and H. Nguyen, "A submerged membrane hybrid system coupled with magnetic ion exchange (MIEX) and flocculation in wastewater treatment," Desalination, vol. 216, no. 1-3, pp. 325-333, 2007.

[37] E. M. Rodríguez, G. Fernández, N. Klamerth, M. I. Maldonado, P. M. Álvarez, and S. Malato, "Efficiency of different solar advanced oxidation processes on the oxidation of bisphenol A in water," Applied Catalysis B: Environmental, vol. 95, no. 3-4, pp. 228-237, 2010.

[38] P. Fernández, J. Blanco, C. Sichel, and S. Malato, "Water disinfection by solar photocatalysis using compound parabolic collectors," Catalysis Today, vol. 101, no. 3-4, pp. 345-352, 2005.

[39] ISO 11268-1, Soil Quality-Effects of Pollutants on EarthwormsPart 1: Determination of Acute Toxicity to Eisenia fetida/Eisenia andrei, 2007.

[40] US EPA, "Ecological effects test guidelines-Earthworm Subchronic Toxicity Test," United States Environmental Protection Agency Federal Register, vol. 96, p. 167, 1996.

[41] OECD, "Test no. 207: earthworm, acute toxicity tests," in Guideline for Testing of Chemicals, 1984.

[42] M. H. Habibi, A. Hassanzadeh, and S. Mahdavi, "The effect of operational parameters on the photocatalytic degradation of three textile azo dyes in aqueous $\mathrm{TiO}_{2}$ suspensions," Journal of Photochemistry and Photobiology A: Chemistry, vol. 172, no. 1, pp. 89-96, 2005.

[43] R. Jain and S. Sikarwar, "Photodegradation of hazardous dye naphthol yellow s over titanium dioxide," Journal of Dispersion Science and Technology, vol. 32, no. 9, pp. 1345-1352, 2011.

[44] T. S. Natarajan, M. Thomas, K. Natarajan, H. C. Bajaj, and R. J. Tayade, "Study on UV-LED/ $\mathrm{TiO}_{2}$ process for degradation of rhodamine B dye," Chemical Engineering Journal, vol. 169, no. 1-3, pp. 126-134, 2011.

[45] S. A. Ong, O. M. Min, L. N. Ho, and Y. S. Wong, "Comparative study on photocatalytic degradation of mono azo dye acid orange 7 and methyl orange under solar light irradiation," Water, Air, \& Soil Pollution, vol. 223, no. 8, pp. 5483-5493, 2012.

[46] V. Augugliaro, C. Baiocchi, A. B. Prevot et al., "Azo-dyes photocatalytic degradation in aqueous suspension of $\mathrm{TiO}_{2}$ under solar irradiation," Chemosphere, vol. 49, no. 10, pp. $1223-$ 1230, 2002.

[47] K. Tanaka, K. Padermpole, and T. Hisanaga, "Photocatalytic degradation of commercial azo dyes," Water Research, vol. 34, no. 1, pp. 327-333, 2000.

[48] X. Chen, W. Wang, H. Xiao et al., "Accelerated $\mathrm{TiO}_{2}$ photocatalytic degradation of Acid Orange 7 under visible light mediated by peroxymonosulfate," Chemical Engineering Journal, vol. 193194, pp. 290-295, 2012.

[49] C. Galindo, P. Jacques, and A. Kalt, "Photodegradation of the aminoazobenzene acid orange 52 by three advanced oxidation processes: $\mathrm{UV} / \mathrm{H}_{2} \mathrm{O}_{2}, \mathrm{UV} / \mathrm{TiO}_{2}$ and $\mathrm{VIS} / \mathrm{TiO}_{2}$ : comparative mechanistic and kinetic investigations," Journal of Photochemistry and Photobiology A: Chemistry, vol. 130, no. 1, pp. 35-47, 2000.

[50] K. Wang, J. Zhang, L. Lou, S. Yang, and Y. Chen, "UV or visible light induced photodegradation of $\mathrm{AO} 7$ on $\mathrm{TiO}_{2}$ particles: the influence of inorganic anions," Journal of Photochemistry and Photobiology A: Chemistry, vol. 165, no. 1-3, pp. 201-207, 2004.

[51] N. Daneshvar, M. Rabbani, N. Modirshahla, and M. A. Behnajady, "Kinetic modeling of photocatalytic degradation of Acid Red 27 in $\mathrm{UV} / \mathrm{TiO}_{2}$ process," Journal of Photochemistry and Photobiology A: Chemistry, vol. 168, no. 1-2, pp. 39-45, 2004.

[52] D.-H. Tseng, L.-C. Juang, and H.-H. Huang, "Effect of oxygen and hydrogen peroxide on the photocatalytic degradation of monochlorobenzene in $\mathrm{TiO}_{2}$ aqueous suspension," International Journal of Photoenergy, vol. 2012, Article ID 328526, 9 pages, 2012.

[53] J. M. Dostanić, D. R. Lonĉarević, P. T. Banković, O. G. Cvetković, D. M. Jovanović, and D. Z. Mijin, "Influence of process parameters on the photodegradation of synthesized azo pyridone dye in $\mathrm{TiO}_{2}$ water suspension under simulated sunlight," Journal of Environmental Science and Health, Part A: Toxic/Hazardous Substances and Environmental Engineering, vol. 46, no. 1, pp. 7079, 2011.

[54] Y. L. Pang and A. Z. Abdullah, " $\mathrm{Fe}^{3+}$ doped $\mathrm{TiO}_{2}$ nanotubes for combined adsorption-sonocatalytic degradation of real textile wastewater," Applied Catalysis B: Environmental, vol. 129, pp. 473-481, 2013.

[55] A. H. Gemeay, I. A. Mansour, R. G. El-Sharkawy, and A. B. Zaki, "Kinetics and mechanism of the heterogeneous catalyzed oxidative degradation of indigo carmine," Journal of Molecular Catalysis A: Chemical, vol. 193, no. 1-2, pp. 109-120, 2003.

[56] S. Haji, B. Benstaali, and N. Al-Bastaki, "Degradation of methyl orange by $\mathrm{UV} / \mathrm{H}_{2} \mathrm{O}_{2}$ advanced oxidation process," Chemical Engineering Journal, vol. 168, no. 1, pp. 134-139, 2011. 
[57] S. Senthilkumaar and K. Porkodi, "Heterogeneous photocatalytic decomposition of crystal Violet in UV-illuminated sol-gel derived nanocrystalline $\mathrm{TiO}_{2}$ suspensions," Journal of Colloid and Interface Science, vol. 288, no. 1, pp. 184-189, 2005.

[58] D. E. Santiago, J. M. Doña-Rodríguez, J. Araña et al., "Optimization of the degradation of imazalil by photocatalysis: comparison between commercial and lab-made photocatalysts," Applied Catalysis B: Environmental, vol. 138-139, pp. 391-400, 2013.

[59] I. Othman, R. M. Mohamed, I. A. Ibrahim, and M. M. Mohamed, "Synthesis and modification of ZSM-5 with manganese and lanthanum and their effects on decolorization of indigo carmine dye," Applied Catalysis A: General, vol. 299, no. 1-2, pp. 95-102, 2006.

[60] A. Mittal, J. Mittal, and L. Kurup, "Batch and bulk removal of hazardous dye, indigo carmine from wastewater through adsorption," Journal of Hazardous Materials, vol. 137, no. 1, pp. 591-602, 2006.

[61] C. Sriwong, S. Wongnawa, and O. Patarapaiboolchai, "Recyclable thin $\mathrm{TiO}_{2}$-embedded rubber sheet and dye degradation," Chemical Engineering Journal, vol. 191, pp. 210-217, 2012.

[62] Z. Peng, H. Tang, and K. Yao, "Recyclable $\mathrm{TiO}_{2} /$ carbon nanotube sponge nanocomposites: controllable synthesis, characterization and enhanced visible light photocatalytic property," Ceramics International, vol. 41, no. 1, part A, pp. 363-368, 2015.

[63] L. L. Costa and A. G. S. Prado, " $\mathrm{TiO}_{2}$ nanotubes as recyclable catalyst for efficient photocatalytic degradation of indigo carmine dye," Journal of Photochemistry and Photobiology A: Chemistry, vol. 201, no. 1, pp. 45-49, 2009.

[64] Y. Lv, L. Yu, X. Zhang, J. Yao, R. Zou, and Z. Dai, "P-doped $\mathrm{TiO}_{2}$ nanoparticles film coated on ground glass substrate and the repeated photodegradation of dye under solar light irradiation," Applied Surface Science, vol. 257, no. 13, pp. 5715-5719, 2011.

[65] X. Guohong, L. Guoguang, S. Dezhi, and Z. Liqing, "Kinetics of acetamiprid photolysis in solution," Bulletin of Environmental Contamination and Toxicology, vol. 82, no. 2, pp. 129-132, 2009.

[66] E. M. Saggioro, A. S. Oliveira, D. F. Buss et al., "Photodecolorization and ecotoxicological effects of solar compound parabolic collector pilot plant and artificial light photocatalysis of indigo carmine dye," Dyes and Pigments, vol. 113, pp. 571-580, 2015.

[67] H. Al-Ekabi and N. Serpone, "Kinetic studies in heterogeneous photocatalysis. 1. Photocatalytic degradation of chlorinated phenols in aerated aqueous solutions over $\mathrm{TiO}_{2}$ supported on a glass matrix," The Journal of Physical Chemistry, vol. 92, no. 20, pp. 5726-5731, 1988.

[68] R. Velmurugan and M. Swaminathan, "An efficient nanostructured $\mathrm{ZnO}$ for dye sensitized degradation of Reactive Red 120 dye under solar light," Solar Energy Materials and Solar Cells, vol. 95, no. 3, pp. 942-950, 2011. 

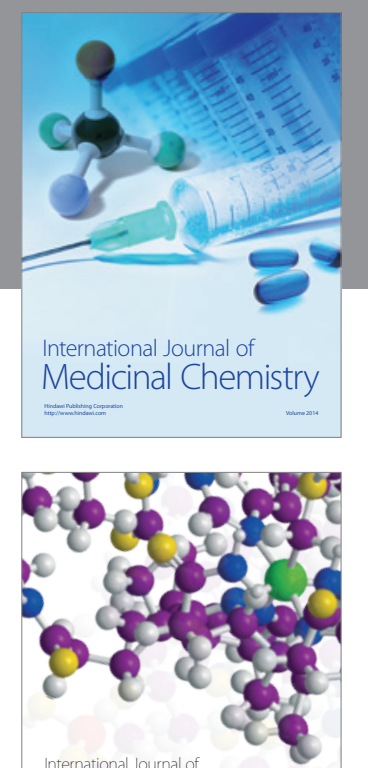

\section{Carbohydrate} Chemistry

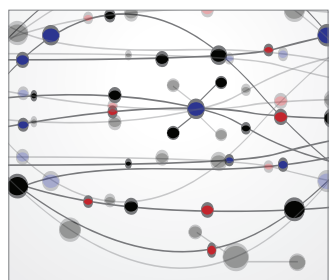

The Scientific World Journal
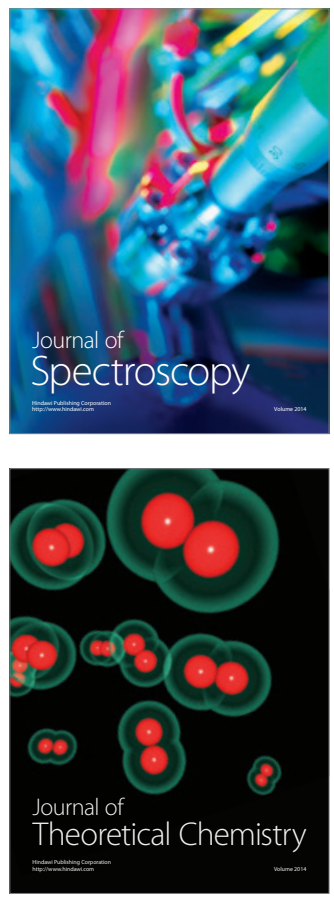
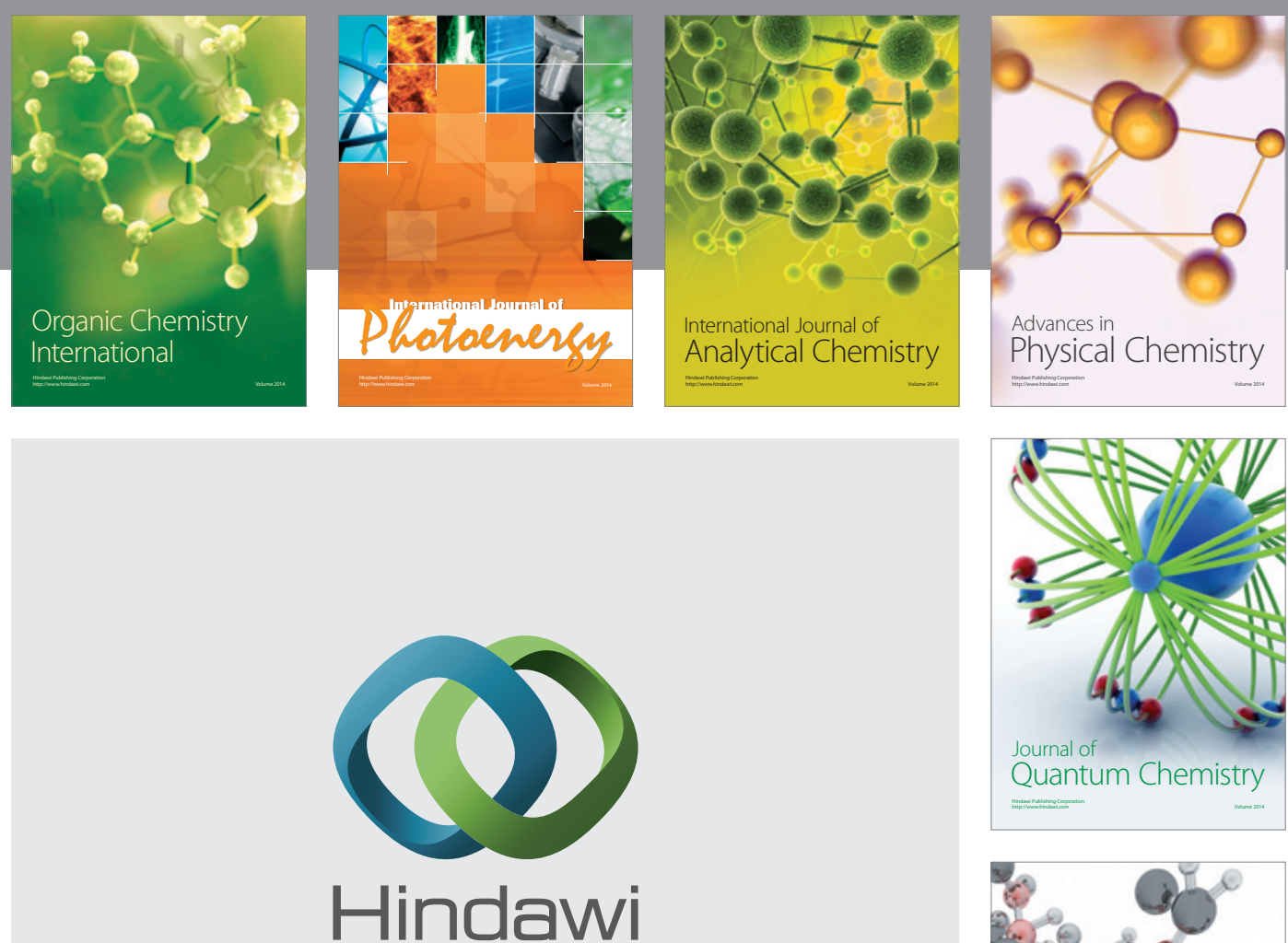

Submit your manuscripts at

http://www.hindawi.com

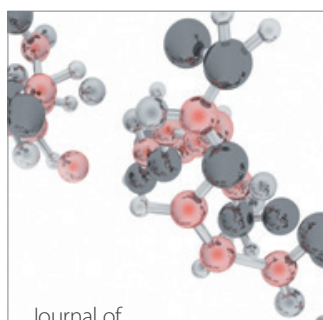

Analytical Methods

in Chemistry

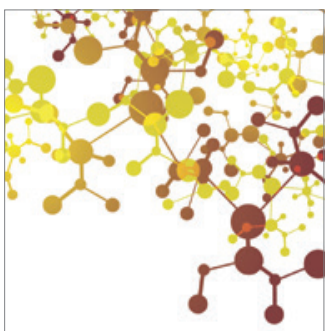

Journal of

Applied Chemistry

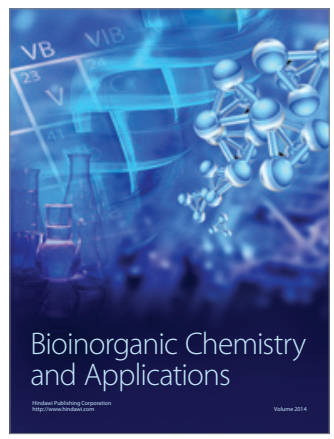

Inorganic Chemistry
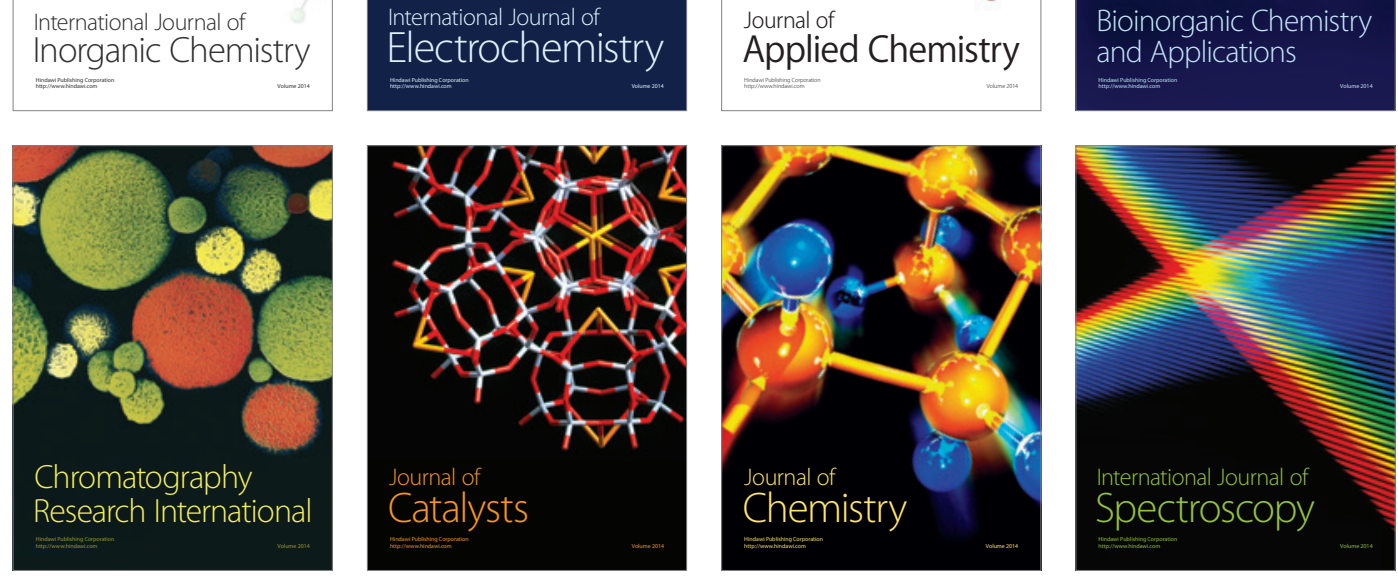